\title{
Policy on Fulfilling the Rights of Persons with Disabilities in Indonesia: Quo Vadis?
}

\author{
Jeremia Gom Gom Parulian Simanjuntak ${ }^{1}$ \\ ${ }^{1}$ Department of Public Administration, Parahyangan Catholic University, \\ Bandung, Indonesia.
}

\begin{abstract}
The Law on persons with disabilities is an aspiration and hope in achieving equality, equal rights and opportunities for persons with disabilities in Indonesia. The implementation of this law is currently not well implemented and has not succeeded in creating equality, equal rights and opportunities for persons with disabilities in their social life. Persons with disabilities still experience various difficulties in their social life and their rights are often neglected. The method used in writing this article is a qualitative method with a descriptive approach. The data collection technique is done by studying the literature. This article is intended to provide an overview of the implementation of the law on persons with disabilities in Indonesia and provide an overview of the situation of persons with disabilities after the law was passed.
\end{abstract}

Keywords: Policy Implementation, Fulfillment of Rights, Persons with Disabilities.

\section{Research Background}

Fulfilling the rights of persons with disabilities is an obligation for every country and is a global issue. Through United Nations (UN) Resolution No. 61 of 2006 concerning the Convention on the Right of Persons with Disabilities (CRPD), there is a paradigm shift and approach to persons with disabilities. Fulfilling the rights of persons with disabilities is no longer for charity purpose only (Charity Based) but is a form of the fulfillment of human rights (Human Rights Based), which is also a human right of a citizen. However, even though the CRPD has been ratified by 166 countries, more work remains to be done to make the country's laws and domestic systems compatible with the CRPD. There is a striking disconnect between the vision set out in the CRPD and the reality experienced by the majority of persons with disabilities in the world (Hussey et al., 2017).

Indonesia ratified the CRPD which was previously signed in 2007 and then regulated in national regulations in 2011, namely through the passage of Law Number 19 of 2011 concerning Ratification of the Convention on the Rights of Persons with Disabilities (Convention on the Rights of Persons with Disabilities). Ratification of Law No. 19 of 2011 concerning Ratification of the Convention on the Rights of Persons with 
Disabilities, followed by the issuance of Law Number 8 of 2016 concerning Persons with Disabilities to strengthen the rights of persons with disabilities in a comprehensive manner.

Persons with Disabilities according to Law Number 8 of 2016 are every person who experiences physical, intellectual, mental, and or sensory limitations for a long period of time who in interacting with the environment can experience obstacles and difficulties to participate fully and effectively with other citizens based on equal rights.

Based on the latest data released by the Ministry of Social Affairs based on the results of the 2018 National Socio-Economic Survey, conducted by the Central Statistics Agency, it was noted that as of 2018 , the number of persons with disabilities in Indonesia was 30.38 million people or $14.2 \%$ of the total population of Indonesia. Persons with disabilities constitute a minority in society, will be but with all the limitations they face, persons with disabilities is also an Indonesian citizen who secured the role, rights and obligations in the Constitution. That is why the government has an obligation to ensure that The rights of persons with disabilities are fulfilled as the government guarantees and fulfills the rights of people who do not have physical disabilities or "normal" communities.

But the current reality is different, because after approximately four years the Law on Persons with Disabilities was passed, in fact not much has changed in terms of fulfilling the rights of persons with disabilities, persons with disabilities still encounter many difficulties and obstacles living in society, especially related to the fulfillment of facility rights and accessibility for them.

Based on data on the results of the 2019 Compliance Assessment of Service Provider Service Standards in accordance with Law No. 25 of 2009 concerning Public Services issued by the Ombudsman of the Republic of Indonesia, the majority of public service delivery within Ministries, Institutions, Provincial Governments, City \& District Governments has not been able to provide special services for service users with special needs. The components of public service standards that are most often violated are the availability of special services for users with special needs and the rights of groups with disabilities to get easy and proper access and facilities.

The disability community itself has also expressed their disappointments related to the fact that their rights are still not fulfilled in social life, on the commemoration of World Disability Day on December 3, 2020, Jaringan Disabilitas Nusantara gave a statement which broadly highlights that the government is still very slow in implementing the Law on Persons with Disabilities. Various studies related to persons with disabilities in Indonesia have been widely carried out, and the majority of the results of these studies still show a "disharmony" between the existing regulations 
related to persons with disabilities and the reality in the field. Regulations have been very clearly set up to be but in practice is still far from expectations.

Some of these studies provide an overview in terms of facilities and accessibility in public transportation (Parulian, et. al, 2019), in terms of communication accessibility rights (Luhulima, 2018), in terms of legal protection in air transportation (Putra, 2019) and in terms of labor rights (Shaleh, 2018), the government is still unable to fulfill the rights of persons with disabilities even though it has been regulated in the Law on Persons with Disabilities.

Phenomenon and indications of problems related to persons with disabilities in Indonesia are a form of governance that is designed and organized uniformly without anticipating that not all communities are in the same condition, for example persons with disabilities, which of course require different needs and treatments in their lives. Although there have been regulations related to the protection and fulfillment of the rights of persons with disabilities, both at the international and national levels, in reality, in the implementation process some of these regulations have not been properly implemented and the rights of persons with disabilities are still being violated and neglected.

\section{Method}

The method used in writing this article is a qualitative method with a descriptive approach. According to Creswell (2010, p.5), qualitative research is methods for exploring and understanding the meaning that some individuals or groups of people think come from social / human problems.

In writing this article, the data collected and used is secondary data in the form of books, articles from scientific journals, research reports and other data related to the theme of the article. In collecting the necessary information and data, we use literature study data collection techniques.

The data analysis technique used is the data analysis technique model of Miles \& Huberman (1992), which consists of:

1. Data Reduction.

2. Data Display (Presentation of Data).

3. Conclusion Drawing/Verification.

\section{Discussion}

\subsection{Policy for Persons with Disabilities in Indonesia}

Judging from existing policies, relating to the protection and fulfillment of the rights of persons with disabilities, Indonesia has a Law which specifically regulates persons with disabilities which was first issued in 1997, namely Law No. 4 of 1997 concerning Persons with Disabilities. This law still uses the old approach, namely the 
health approach in viewing persons with disabilities. At that time, persons with disabilities were still considered sick individuals and deserving of pity.

Then, in 2016 Indonesia changed the law-to-Law No. 8 of 2016 concerning Persons with Disabilities that uses a social and human rights approach, and currently persons with disabilities are seen as part of human diversity and have the same and equal human rights as other individuals. In Law no. 8 of 2016 concerning Persons with Disabilities has regulated the rights of persons with disabilities in a comprehensive manner.

Broadly speaking, the Law on Persons with Disabilities regulates the types of Persons with Disabilities, the rights of Persons with Disabilities, the implementation of respect, protection and fulfillment of the rights of Persons with Disabilities. With the existence of this law, it strengthens better rights and opportunities for persons with disabilities. Starting from the right to life, the right to a decent job, better education and easy access to public facilities and other rights.

If viewed from existing policies, the rights of persons with disabilities in their lives as citizens have been clearly regulated in the law on persons with disabilities, meaning that there is a strong foundation and clear indicator in fulfilling the rights of persons with disabilities. This regulation on the protection of persons with disabilities should provide a solid basis for fulfilling the rights of persons with disabilities in Indonesia.

Therefore, it can be concluded that in fact in the implementation of governance in Indonesia both at the central and regional levels, it should be implemented based on the law on persons with disabilities and can fulfill all the rights of society, is nondiscriminatory and inclusive.

\subsection{Implementation of the Law on Persons with Disabilities in Indonesia}

Policy implementation is a very important stage in the entire process and structure of a policy, because through this implementation process the policy process as a whole can be influenced by the level of success or achievement of its objectives. This was emphasized by Udoji (Agustino, 2006, p. 154) by suggesting that policy implementation is something that is important, maybe even more important than policy making. Policies will simply be dreams or good plans tucked away in the archives if they are not implemented.

In analyzing the implementation process of the law on persons with disabilities, the author uses the Van Meter \& Van Horn theory (Subarsono, 2013, p. 99) which suggests six variables that affect the success of public policy performance, namely:

1. Policy targets and standards.

2. Resources.

3. Relations between Organizations. 
4. Characteristics of Implementing Agents.

5. Social, Political and Economic Conditions.

6. Implementer Disposition.

Meanwhile, regarding the implementation of the disability policy, Schalock \& Keith (Verdugo et. al, 2017) argued that the successful implementation of the disability policy was influenced by a number of cultural factors. This includes:

1. The level of socio-economic development of the country or region.

2. Democratic traditions, and

3. The main political will and ideology of the current government.

In addition, policy implementation is affected by a number of issues, including approaches to understanding disabilities, the structure and function of service delivery systems, the degree of organizational and systems transformation.

Based on these two theories, the policy implementation process, especially in the context of policy implementation for persons with disabilities, the readiness of a country's government plays a major role in determining the failure or success of implementing a policy for persons with disabilities. A country is demanded to be prepared in socio-economic, democratic and political traditions to be able to implement a policy for persons with disabilities properly.

In the analysis and discussion for this article, of the six variables proposed by Van Meter \& Van Horn, the author will focus on the social, political and economic environmental variables. Because in addition to other variables that influence the policy implementation process, the authors argue that the social, political and economic environment variables as the external environment of policy play a major role in influencing the failure or success of implementing a policy. This is also reinforced by the opinion of Schalock \& Keith regarding the policy implementation process for persons with disabilities which is strongly influenced by socio-economic factors, democratic traditions and politics.

In the context of the law on persons with disabilities, the socio-economic conditions of society, perceptions and interpersonal relationships between persons without disabilities and persons with disabilities can greatly influence the success of the implementation of the law on persons with disabilities, as well as political conditions, because it cannot be denied that a policy was born from the results of the political process, therefore it is necessary to look at the political aspects of the law on persons with disabilities so that later we can find out the impact or influence on the implementation process of the law on persons with disabilities. 


\subsection{Aspects of Social, Political and Economic Conditions in the Implementation of the Law on Persons with Disabilities in Indonesia}

Broadly speaking, Van Meter \& Van Horn suggested that the social, economic and political conditions of the environment can influence the success of the policy implementation process, the extent to which interest groups provide support for policy implementation, then the characteristics of the participants whether they support or reject and what is the nature of existing public opinion in the environment, and whether the political elite supports policy implementation.

\subsection{Socio-Economic Environmental Aspects of Society}

The socio-economic condition of the community is an important thing in order to support the running of a policy. This is because a society that is already open and educated will be relatively easier to accept changes compared to a society that is still closed and traditional. The law on persons with disabilities is a revolutionary law, because it brings major changes and changes the way people perceive persons with disabilities. In this discussion, the author will focus on the social environment and interpersonal relationships between persons with disabilities and persons without disabilities.

In my opinion, persons without disabilities play a big role in supporting the successful implementation of this policy for persons with disabilities, because equality can only be created when the government, persons without disabilities and persons with disabilities respect and collaborate to realize what is mandated by the law on persons with disabilities, this is the principle of Collaborative Policymaking \& Adaptive Implementation (Ansell, 2017), where a policy must be made and implemented based on collaboration between policy actors vertically and horizontally so that a policy can be implemented effectively.

However, the problem is the current tendency of the general public to have a different view of the disabilities around them and persons with disabilities still face a strong social stigma in society. It has been a long time since the community considered that the existence of persons with disabilities was something that was troublesome for them. There are even those who consider that the existence of persons with disabilities is a family disgrace, is considered to be the source of the problem, so that it is considered a sin. In the end, this will further complicate the position of persons with disabilities in their interactions in the social environment.

There are five perspectives that influence the way the wider community thinks about disability issues. The fifth way of viewing include the moral point of view, compassion, health, social, and human rights (MDRC, 2001; Miller \& Ziegler, 2006; Worm, 2012). Three way first sight (of morality, mercy, and health) focuses on the limitations of people with disabilities; This perspective contributes to the social exclusion from the environment experienced by persons with disabilities. Meanwhile, two-way view of the 
last (social model and human rights) is more focused on the conditions of the community, the environment, and institutional role in creating conditions of disability (Hastuti et. al, 2020).

Current public perceptions or views of persons with disabilities slightly change, this can be seen from the growth of community organizations that make issues of equality for persons with disabilities their main focus, such as Konekin Indonesia organization which was founded in 2018, Rumah Disabilitas founded in 2020 and Code For Social founded in 2020. The three organizations focus on creating an inclusive ecosystem in Indonesia (Konekin Indonesia), fighting for disability rights and youth concern for disability issues (Rumah Disabilitas) and providing vocational education such as coding and programming to persons with disabilities (Code For Social). The three organizations are organizations founded by young people who care about people with disabilities and the fulfillment of their rights. This is of course a positive change, and it is hoped that through these community organizations it can help to change people's perceptions of persons with disabilities in general.

However, it must be acknowledged that the current state of public perceptions and views of persons with disabilities overall is tend to be negative and are still one of the problems in achieving equal rights and opportunities in the social environment. To provide an illustration, the author will present the results of a literature study regarding the conditions of community and the relations between persons without disabilities and persons with disabilities.

Referring to a study report published by the SMERU Research Institute in 2020, the following findings are presented:

1) When interacting with families, especially in rural areas, persons with disabilities are often seen as a source of shame or family shame so that families choose to lock up persons with disabilities at home and do not allow them to interact with the environment, go to school, or work, and do not even record them in population data (Human Rights Watch, 2016; Sucahyo, 2016).

2) When interacting with the surrounding community, persons with disabilities are often underestimated and their dignity as human beings is not respected. They, especially persons with psychosocial disabilities, are often called negative names, such as "crazy people" and "slanted brains". They are also often neglected and given the stigma that they "could never" or "could not possibly" do something. They are considered unproductive, and even thrown stones and being abused (Anugrahadi, 2017; Human Rights Watch, 2016; Wijayanti, 2016).

3) In interactions in a formal environment, such as at school and work. Students with disabilities in inclusive schools often receive bullying from friends and discriminatory treatment from teachers. 
4) In the world of work, persons with disabilities experience stigma and discriminatory treatment from job providers. Some of the stigma and negative behavior from companies towards persons with disabilities include the assumption that persons with disabilities cannot work (Hardi, 2018). Many employers also do not know the terminology of disability, and many do not even know that workers with disabilities exist (Hardi, 2018).

Based on the findings data that have been previously presented, we get a picture that at this time the relationship between non-disabilities persons and persons with disabilities is still not fully showing a good relationship and the society still have negative perceptions of persons with disabilities. This condition is of course an obstacle to achieving equality, equal rights and opportunities as mandated by the law on persons with disabilities.

In terms of public policy, according to Quade (Akib, 2010) that the successful implementation of public policies is not only influenced by internal factors, but also influenced by external factors, namely the environment in which the policy is implemented. However the magnitude of the work done by the implementor of policies, would but if the regulatory environment does not support, then the policy can fail to be implemented.

Quade (Akib, 2010) argues that the creation of a situation and conditions for the policy environment is needed in order to have an effect, even though the influence is often positive or negative, therefore it is assumed that if the environment has a positive view of a policy it will generate positive support so that the environment affects the success of policy implementation. and vice versa, if the environment has a negative view, there will be a clash of attitudes so that the implementation process is threatened with failure.

In the context of the law on persons with disabilities, the external environment of this policy is the social environment of society in general, where the policy is implemented, and non-disabilities persons are also part of it. Therefore, non-disabilities persons can influence the failure or success of the policy to be implemented, because it is an integral part of the social environment together with persons with disabilities. It's just that, as the author pointed out earlier, collaboration is needed between the government, non-disabilities persons and persons with disabilities to realize the ideals set forth in the law on persons with disabilities.

Because it must be admitted that the government does have a major role, will be but the government cannot stand on its own, especially in dealing with persons with disabilities problem which is a complex problem and requires the collaboration of various parties to resolve. 


\subsection{Collaborative Policymaking \& Adaptive Implementation as Alternative Solutions}

Collaborative Policymaking according to Ansell (2017) is a new perspective to overcome implementation problems and emphasizes that collaborative policy design and adaptive implementation will help policy makers to improve policy implementation. Ansell emphasized that to improve policy implementation we must go further and consider how policies can be designed more effectively by connecting actors vertically and horizontally in a process of collaboration and collective deliberation.

The concept of Collaborative Policymaking put forward by Ansell emphasizes that there are at least five different ways that collaboration can facilitate adaptive implementation. First, collaboration with frontline staff and their representatives can help public leaders responsible for policy implementation to understand conditions on the ground and how they differ from place to place and between institutions. Second, collaboration with frontline staff can help identify needs in terms of skills, competencies and resources and encourage organizational learning and ongoing experimentation that will increase the production and delivery of new services. Third, collaboration with local stakeholders not only generates political support and supportive action from relevant stakeholders, but also collects constructive feedback on proposed policy solutions that can encourage policy learning and incremental adjustments. Fourth, the collaboration with the relevant actors and those affected, providing an early warning system that can help detect problems when it is still small and make a rapid response and agreed to new conditions by way of cutting the traditional command lines. Fifth, collaboration with clients and target groups that goes beyond user satisfaction surveys and complaint services can spur the co-production of public services and the co-creation of new and better solutions.

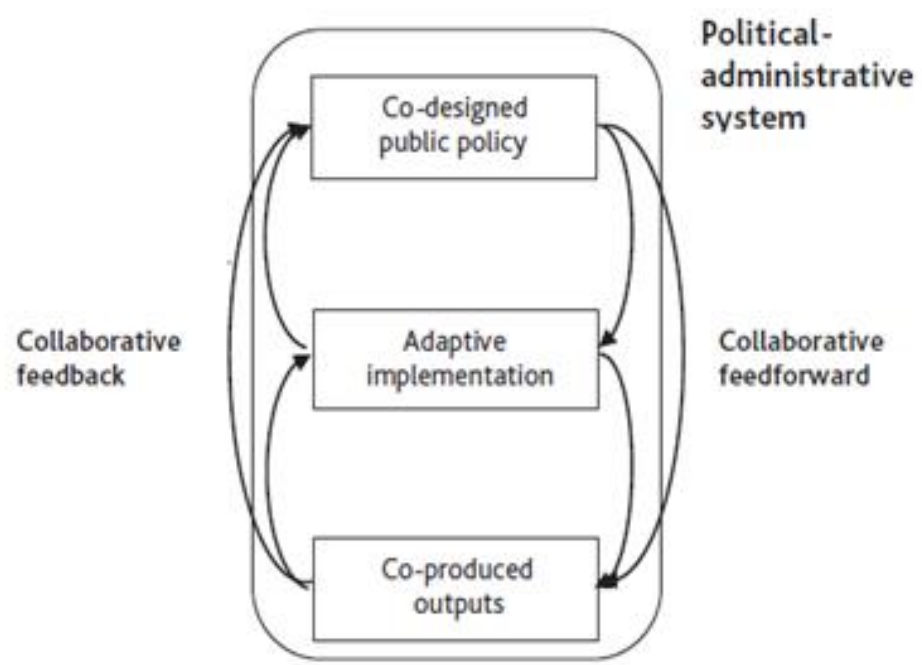

Figure 1.The New Collaborative Policymaking Model (Ansell, 2017) 
The government can implement adaptive implementation as part of the collaborative policymaking process proposed by Ansell as an alternative solution to the successful implementation of the law on persons with disabilities, the central government can create collaboration between the central government, local governments as local stakeholders, non-disabilities persons and persons with disabilities. This is because various parties need to be involved, especially the nondisabilities persons as one of the groups of people who are also affected by the law on persons with disabilities, because this law obliges every citizen to respect and respect the rights of persons with disabilities.

With the fact that the general public's understanding of disability issues is still low as previously described, the central and local governments need to collaborate with the wider community by opening discussion forums, providing education, and aggressively disseminating the law on persons with disabilities to strengthen public understanding related disability issues.

Because based on the research conducted by the author, there are no traces of publications related to discussion forums or socialization of the law on persons with disabilities by the government to the wider community, this is of course very unfortunate, given the current situation, where the general public's understanding of the issue is still low on disability issues.

This aspect of the social environment of society needs to be improved first, because persons with disabilities are also part of the social environment of society and interact directly with the wider community. When the social environment of the community has become more "friendly" to persons with disabilities, there is a sense of togetherness to improve the quality of life of persons with disabilities, and accept disabilities as a human diversity, then the implementation of the law on persons with disabilities will be carried out better, due to broad public support is a strong foundation for the success of a public policy.

\subsection{Aspects of the Political Environment}

Public policy is the result of a political process, and the implementation process cannot be separated from the political process. The process of public policy analysis is a series of intellectual activities carried out in the process of political activity. These political activities appear in a series of activities that include agenda setting, policy formulation, policy adoption, policy implementation, and policy assessment (Subarsono, 2013, p. 8).

Therefore, it is impossible to separate public policy and politics, because these two things are part of a process that is interrelated in the broad framework of the process of the birth of a public policy. In fact, public policies are not easy to make, not easy to implement and not easy to control because public policies involve politics. 
In the context of the law on persons with disabilities, even this policy is not a policy that is "neutral" from politics, but is also a policy that is born out of a political process. This policy was born out of the demands of the disability community for equality in every area of life, which was then responded by the government. This government's response is reasonable, because it refers to systems theory, public policy making cannot be separated from environmental influences, demands for policies can be generated due to environmental influences, and then transformed into a political system (Subarsono, 2013, p. 14).

Regarding the political aspects of the law on persons with disabilities, if we look at the process of its birth, it can be said that the law on persons with disabilities is one of the issues that has been successfully put forward into a policy or law and is a symbol of the success of the struggle for the disability movement in achieving equality, equal rights and opportunities in people's lives.

Referring to the systems theory previously put forward, the disability issue has succeeded in influencing the government and the political system which then responds to it into a policy, even though it has gone through a very long process. This is because in fact not all issues have succeeded in becoming a law, one example is the issue of sexual violence which is currently still a draft law and has not yet been passed into a law.

If we judge from the process of its birth, the law on persons with disabilities has succeeded in gaining support from the political environment. However, if we look at it as a whole, the support for the political environment cannot stop only at the birth of this law, but also requires support up to the implementation stage.

The current situation, according to the author, gives the impression that support from the political environment, namely the government and the political system, is felt to be "running out of gasoline", because the current implementation process seems stuck and there are still many people with disabilities whose rights have not been fulfilled as regulated in the law on persons with disabilities.

"Running out of gasoline" can also be interpreted as starting to wane the political will of government officials and other political officials in resolving disability issues as stated in the law on persons with disabilities, because it cannot be denied that the political will of government officials and political officials affects the implementation process of public policy (Wibawa, 1994).

On the commemoration of World Disability Day on December 3, 2020, Jaringan Disabilitas Nusantara stated their findings regarding the still weak efforts of the government in the process of implementing the law on persons with disabilities, namely:

1. The government has been very slow in implementing and implementing Law No. 8 of 2016. This is reflected in: 
a. The delay in making Peraturan Pemerintah (PP)/Government Regulations, which should be completed in April 2018, but only made in 2020, and even then only 6 PP out of 8 PP must be made.

b. Referring to Law Number 8 of 2016, that the National Commission on Disabilities should have emerged in the month of April 2019, will be but until now has not been formed.

2. PP formed not managed to change the system, especially in the way of viewing mandated by Law No. 8 of 2016 and the establishment of the existing PP was initiated by DPO (Disabled People Organization), will be but the harmonization process change, because the DPO is not involved in the process to end. The formation of PP in the harmonization stage often changes the substance that is an important point for persons with disabilities, because there is no involvement of persons with disabilities in the finalization of PP.

3. The lack of persons with disabilities participation in various policies, for example: the Asian Para-Games, which carries the idea of inspiration-porn. This happens because persons with disabilities are hardly involved. The minimal involvement of persons with disabilities is also in the process of making the National Action Plan/RAN (Rencana Aksi Nasional) and the Regional Actional Plan/RAD (Rencana Aksi Daerah) for disabilities, which President Joko Widodo is in the process of. The minimal participation of persons with disabilities is due to lack of accessibility and is not even announced or restricted. There is only a small part of the overall process for participation.

4. Lack of public transparency and public accountability. example : websites, documents, and materials. Many state-owned materials, documents, and public facilities are not friendly to persons with disabilities. The average score for the accessibility of state institutions' websites is only 70, below the standard of accessibility for persons with disabilities, especially images without alternative text and audio without transcripts or captions.

5. Not harmonizing existing regulations with Law No. 8 of 2016, for example: the Cipta Kerja Law which uses the word disabled to refer to persons with disabilities and allows a worker who has become a disability to be dismissed.

6. There is no harmonization of budget nomenclature related to the needs of persons with disabilities, for example: SBM, Ministry of Finance, standards for procurement of goods and services. The needs of persons with disabilities such as: Sign Language Interpreters, companions, and others have not yet become items in the input cost standard and also the standard for procurement of goods. This has resulted in various agencies having difficulty allocating budgets to the needs of persons with disabilities.

7. There is no roadmap to fulfill the target of $2 \%$ (for government agencies) and $1 \%$ (for private agencies) in recruiting persons with disabilities. Even in the Cipta Kerja Law it says that according to Article 154A, workers who experience work accidents and result in disabilities can be dismissed for at least 12 months. 
8. The lack of facilitation/support from the government for persons with disabilities in education, such as:

a. Scholarships for persons with disabilities

b. Only 15 universities have Disability Service Units from more than 4000 universities

c. Lack of special companion teachers, etc.

Through these data, in general, an illustration shows that government support seems to have decreased to fully support the implementation of the law on persons with disabilities. Because if we take it back, the current government has actually paid attention to disability issues, President Joko Widodo himself was recorded in two presidential elections, namely in 2014 and 2019 making political promises to fulfill the rights of persons with disabilities and create equality, equal rights and opportunities for persons with disabilities in all fields.

However, the current reality is that there are still many shortcomings in the implementation process of the law on persons with disabilities, especially in relation to the completeness of supporting regulations and the absence of a National Commission for Disabilities, because when referring to the law on persons with disabilities, the National Commission for Disabilities has a very important task, namely carry out monitoring, evaluation and advocacy for the implementation of respect, protection and fulfillment of the rights of persons with disabilities.

If viewed from a political perspective, it is actually related to persons with disabilities, it must be admitted that persons with disabilities are not the majority group in the political system. The political system is still exclusive and groups of persons with disabilities have a small voice when compared to other groups in society in general and it is difficult to be able to influence the government and the political system. Throughout history, persons with disabilities have experienced systematic discrimination and exclusion from national issues including those that directly affect them (Schur et. al, 2002).

As has been stated earlier that public policy is the result of the political system, government officials are the result of the political system through the general election process. Therefore, as something that is born from the political system, the problems of the majority and minority are everything, the majority group that has a dominant voice will be able to pressure the government more strongly than minority groups who have a bargaining position and little political benefits, and this is not the case which is really strange, because the general election system is sometimes just a matter of lose-win and popularity-electability and the opinion of the majority group as the main foundation. For minority groups such as persons with disabilities, it must be admitted that they are often marginalized. 
Regarding how strong public opinion can pressure the government, Jacobs \& Shapiro (Sobari, 2013) calls the term "under fire". According to both, apart from contributing to elections and democracy, opinion polls and public opinion are blamed because elected officials use them excessively. Officials who are supposed to rely on independent considerations of the policies they make and implement prefer public preferences that are estimated through opinion polls.

Ido (2012) argues that in a democratic system, there are two types of democracy, namely: majority democracy (majority power) and consensus or deliberative democracy (strength of agreement). The second type of democracy is known as liberal democracy (value freedom) and social democracy (value equality). For Indonesia, the type of democracy that operates in this country is more inclined towards majority democracy, where the votes and power of the majority still have a stronger role in the political system and democracy.

It cannot be denied that for political officials born from a democratic system and a general election system, public support is everything. If faith is the main foundation of humanity, then public support is the main foundation of a politician. The difference is, if a little faith is able to move the "mountains", but little public support cannot move a politician to the throne of power. Therefore only large public support can deliver politicians to the throne of power through the electoral system.

The electoral system is the biological child of a democratic system, and democracy itself should be more than just the implementation of elections. Noor (2016) argues that democracy is not only seen as an election issue, but a culture and ideology that contains a set of values that must be nurtured, such as equality, participation, freedom, tolerance, justice, universal rights, and the agreement of many people. Therefore, political officials should not only think about the issue of lose-win in elections and make the issue of popularity-electability and opinion of the majority group the most important, but should be able to make elections as a means of accommodating the interests of all groups of people, both the majority and the minority.

\subsection{Become "Opposition" and "Pressure" the Government}

In the political system, the opposition is known as a party that is outside the circle of power in a government and is tasked with carrying out the checks and balances function. Noor (2016) argues that the opposition is a group of people outside the government who legally have the right to voice opinions and carry out activities aimed at criticizing and controlling attitudes, views, or government policies based on ideological perspectives, empirical realities, or certain interests. Meanwhile, the concept of checks and balances itself allows the existing parties, both in the parliament and the executive, to control each other and remind the running of the government to remain in line with the will of the people. 
The disability community can act as "opposition" and "pressure" the government by carrying out a process of checks and balances related to the implementation of the law on persons with disabilities, the disability community can strongly voice input for improvement to the government and to the legislature, so that later the ideals of the law on persons with disabilities can be achieved. The disability community can also collaborate with various parties, such as the National Commission on Human Rights, advocacy organizations, the academic community and other community groups in carrying out the checks and balances process. Because it must be admitted that the situation does require support from various parties and support from the political environment to be able to encourage the government to seriously implement a policy.

\section{Conclusion}

Based on the results of the discussion and analysis, regarding the implementation of the protection policy for persons with disabilities in Indonesia, namely Law Number 8 of 2016 concerning Persons with Disabilities, it is concluded that Indonesia has shown its concern for the persons with disabilities with the issuance of the law on persons with disabilities, but when viewed from the existing circumstances, it seems that it is just a formality of completion of tasks, without being accompanied by an implementation process that is well, this shows that the rights of persons with disabilities have not been fulfilled in social life and there are still many things mandated by this law that have not been fully implemented, such as incomplete supporting regulations and the absence of a National Commission for Disabilities.

The implementation of the law on persons with disabilities requires the support of the social and political environment to be able to make this law successful, the still strong social stigma against persons with disabilities in the social environment and the weak position of persons with disabilities in the political environment affect the process of implementing this law.

\section{References}

Agustino, Leo. (2006). Politik dan Kebijakan Publik. Bandung: AIPI.

Akib, Haedar. (2010). Implementasi Kebijakan: Apa, Mengapa, Dan Bagaimana. Jurnal Administrasi Publik, 1 (1).

Ansell, Christopher. (2017). Improving Policy Implementation Through Collaborative Policymaking. Policy \& Politics, 45 (3), 467-486.

Creswell, John. (2010). Research Design (Pendekatan Kualitatif, Kuantitatif, Mixed). Yogyakarta: Pustaka Pelajar.

Dunn, William. (2003). Pengantar Analisis Kebijakan Publik. Yogyakarta : Gajah Mada University Press. 
Hastuti., Dewi, Kumala, R., Pramana, Rezanti., Sadaly, Hariyanti.(2020). Kendala Mewujudkan Pembangunan Inklusif Penyandang Disabilitas. Jakarta: SMERU Research Institute.

Hussey, Meghan., MacLachlan, Malcolm., Mji, Gubela. (2017). Barriers to the Implementation of the Health and Rehabilitation Articles of the United Nations Convention on the Rights of Persons with Disabilities in South Africa. International Journal of Health Policy and Management, 6 (4), 207-218.

Ido, Masanobu. (2012). Varieties of Capitalism, Types of Democracy and Globalization. New York: Routledge.

Jeremia G.G. Parulian, Budiman Rusli, Elisa Susanti.(2019). Accessibility for Persons with Disabilities in Trans Metro Bandung Services. Indonesian Journal of Disability Studies (IJDS) 6(2), 149-156.

Law Number 8 of 2016 Concerning Persons with Disabilities.

Liputan6 News Portal. (29 January 2021). "Jumlah Penyandang Disabilitas di Indonesia Menurut Kementerian Sosial”. Via: https://www.liputan6.com/disabilitas/read/4351496/jumlah-penyandang-

disabilitas-di-indonesia-menurut-kementerian-

sosial\#: :text=Walaupun\%20sifatnya\%20survei\%2C\%20tetapi\%20informasi,atau \%2030\%2C38\%20juta\%20jiwa

Luhulima, H, Valence.(2018).Implementation Of Devotional Rights On Accessibility And Communication Based On Undang-Undang Nomor 8 Tahun 2016 Concerning Disabilities. Indonesian Journal of Disability Studies (IJDS), 5 (2), 268-295.

Merdeka News Portal. (29 January 2021). "Refleksi Implementasi UU No.8 Tahun 2016, Penyandang Disabilitas Menagih Janji”. Via: https://www.merdeka.com/jabar/refleksi-implementasi-uu-no-8-tahun-2016penyandang-disabiltas-menagih-janji.html

Miles, M.B \& M.A Huberman.1992. Analisis Data Kualitatif. Jakarta: Penerbit Universitas Indonesia

Noor, Firman., (2016). Oposisi Dalam Kehidupan Demokrasi: Arti Penting Keberadaan Oposisi Sebagai Bagian Penguatan Demokrasi Indonesia. Jurnal Masyarakat Indonesia, 42 (1).

Ombudsman Republik Indonesia.2020. Ringkasan Eksekutif Hasil Penilaian Kepatuhan Ombudsman RI Tahun 2019. Jakarta: Ombudsman RI.

Putra, Willy. (2019). Implementation of Law Protection of The Equal Rights For Disability People In Aerial Transportation. Indonesian Journal of Disability Studies (IJDS), 6 (2), 259-268.

Schur, L., Shields, T., Kruse, D., Schriner, K. (2002). Enabling Democracy: Disability and Voter Turnout. Political Research Quarterly, 55 (1), 167-190.

Shaleh, Ismail. (2018). Implementasi Pemenuhan Hak Bagi Penyandang Disabilitas Ketenagakerjaan Di Semarang. Kanun Jurnal Ilmu Hukum, 20 (1), 63-82.

Sobari, Wawan. (2013). Elektabilitas Dan Mitos Pemilih Rasional: Debat Hasil-Hasil Riset Opini Menjelang Pemilu 2014. Jurnal Penelitian Politik LIPI, 10 (1). 
Subarsono. (2013). Analisis Kebijakan Publik Konsep Teori dan Aplikasi. Yogyakarta : Pustaka Pelajar.

Tempo News Portal. (31 January 2021). "Simak Janji Dua Kubu Capres untuk Para Penyandang Disabilitas". Via: https://difabel.tempo.co/read/1180850/simak-janjidua-kubu-capres-untuk-para-penyandang-disabilitas/full\&view=ok

Wibawa, Samodra. (1994). Kebijakan Publik. Jakarta: Intermedia.

Verdugo, Miguel., Jenaro Cristina., Calvo Isabel., Navas Patricia. (2017). Disability Policy Implementation From a Cross-Cultural Perspective. Intellectual And Developmental Disabilities, 55 (4), 234-246. 